\title{
The spiritual world of ordinary life,an analysis on the character of Sun Shaoan in "The Ordinary World"
}

\author{
Qizhen Li \\ Hubei University of Science and Technology. Xianning Hubei ,437005, China
}

Keywords: Ordinary life, Spiritual world, Sun Shaoan.

\begin{abstract}
There are always one or two characters in a great book that impressed you and Sun Shaoping in "The ordinary world" is such a character that people will never forget. He is kind, gentle, rational, pragmatic, tough, tenacious and ambitious. He has deep affections for his family, hometown and the folks. He sacrificed his studies and love for his family. In order to help the folks, he expanded the brick factory and invested in the school building after profitability. All this is to make the villagers live better. In his ordinary life, he made a lot of extraordinary actions.
\end{abstract}

\section{Introduction}

"The ordinary world” is a masterpiece of millions of words written by Lu Yao. The book shows the urban and rural life in China from the mid-1970s to the mid-1980s in a panoramic view. The book is divided into three parts. There are complex contradictions and disputes throughout the text. Life and love, reality and pursuit, choice and life, trivia and the huge social conflicts are intertwined with each other, which shaped the character of the two brothers Sun Shaoan and Sun Shaoping. Mr. Lu Yao preferred Sun Shaoping, but I prefer Sun Shaoan. He has the courage to take on family responsibility, and he is rational and pragmatic. Although he hurt Run Ye when dealing with love rationally and conservatively, but he bore more than Run Ye.

He has the quality of bright, tough, tenacious, optimistic and ambitious, which has inspired a lot of readers.

\section{He is a good son of his hometown}

Family is the spiritual pillar and the main melody in Sun Shaoan's life. There is a warmth of family in the book. The author made a dense description for the family, such as "my dear, my beloved earth, my dear father, my beloved ShuangShui village,etc".These beautiful and warm feelings warm the people who are in trouble, and they are the spiritual motivation. Sun Shaoan is such an ordinary but extraordinary person lives for family in "The ordinary world".

The poor rural life characterized Sun Shaoan as diligent, tenacious, pragmatic and rational. He was more precocious than his peers when he was still a teenager. When his father first wept in front of him, he realized that he had to share responsibilities for the father who was tall in the eyes of his childhood. He saw the bitterness and helplessness in the father who was kind and great in his mind. So he decided to say goodbye to the school forever. As the eldest son of his family, he felt he had a responsibility to support his family. He inherited the fine tradition of rural society. He put the family as a treasure and take it as spiritual support. Family is the motivation that makes him not standstill but get up and fight when encountered setbacks. After the implementation of the responsibility system for production, Sun Shaoan set up a brick factory. His life has been improved by his diligence and steadfast. The new life inspired him a lot. However, the idea of breaking up the family and live apart Xiulian proposed brought him back to distress. He could not accept the fact that his family are split, neither emotionally nor sanely. He has sacrificed his studies and love for the family. 
This family has been a part of his life. In the most painful days, they stood together and got through it. He didn't want to leave the family he sustained. The family is the original motivation to make him fight and full of energy. He wants his parents to live a good life. He cannot let go of kinship .He thinks it's his duty to be in charge of the family. He used his own life trajectory to interpret that there is a strong tradition concept of family in Chinese people. He shines with the moving brilliance that family is supremacy. This kind of warmth comforts the people who are not easy in their lives, making them feel though life is hard, but they still should make unremitting efforts.

Sun Shaoan not only has infinite affection for his family, but also generous and tolerant to his neighbors. He never turned away when the villagers borrowed money from him when he lived a rich life. In order to help the villagers, he even expanded the brick factory, although it was unnecessary. He did not do anything to harm the interests of the villagers for his own. The guileless, considerate, warmhearted and readiness to help have embodied in him vividly. And we can not find a shadow of the narrowness and selfishness of the peasants in him. His spirit is beyond the spiritual level of ordinary people. While, his folks are not so "not ordinary" as him. They didn't give him "timely assistance" when he most deeded it, but Sun Shaoan got the villagers. When the brick factory went bankrupt, he did everything thing to pay their wages. After reconstruction, he recruited them. He is also concerned about the neighborhood folks. For example, the novel says, "policy is policy, human relationship is human relationship", As neighbors of the same village, how can we eat meat, and let the people around us swallow the chaff. His love and righteousness make him shining extraordinary human light on that ordinary land.

\section{He is a good husband who guard the insipid marriage}

Mr. Lu Yao described the hero's behavior and psychology when he treated love and marriage based on the socioeconomic status of the protagonist and the realistic reason in the complex situation. There are two important women in Sun Shaoan's romance, one is the first love Tian Runye, a natinal teacher working in the urban city and paid by government, the other is a girl comes from a mountain village of Shanxi named He Xiulian. He loved the girl he has known since his boyhood Tian Runye, but he chose to marry He Xiulian. In his view, Tian Runye is a national teacher in the city, but he is just a rural farming youth. The difference of social status and economic conditions between them are too great. No matter how deep the feelings are, they cannot eliminate the distance between them. In the contradiction between emotion and reality, the emotion surrender to reality under Sun Shaoan's rational. Sun Shaoan's love branded a deep background of the times. His traditional idea of marriage killed his true feelings for love. Though he understood Tian Runye's heart and infatuation, he kept controlling his feelings. He thinks that to love her is to give her happiness, and he can't give her happiness, so he choose not to love her and do some unreasonable things to her, even married He Xiulian in order to cut off the infatuation of Runye. His behavior of dealing with emotion has greatly distorted his mind and hurt Runye, and also makes himself miserable. This is also the author's revelation of that time[1].

But for He Xiulian, he's a good husband. He Xiulian and He is a real couple who share weal and woe. When He Xiulian married him, she didn't ask for betrothal gifts. The harsh reality made him treat life with realism. In this way, Sun Shaoan live a daily necessities life with a girl he never loved. Perhaps a lot of readers will feel sorry for such a marriage of Shaoan. Just like most young people in rural areas, his marriage is also for the sake of life, without the slightest emotional basis. However, under the arrangement of the author's realism, the simple and plain life is also a kind of happiness. Love is a feeling of happiness and their ordinary marriage is also a form of love. In fact, no matter how vigorous the love is, it will return to the plain life eventually[2]. Their feelings built in the long hard life are much deeper than those ordinary love. Sun Shaoan also grew more and more dependent on their feelings. Finally, the affection between them turned out to be a special power to support him to eliminate difficulties and obstacles in the way of seeking the ideal. Although the author reveals some real problems with the first love of Shaoan, but also gave his marriage a happy aura, which reduces the regret that he didn't marry Runye. But life will not always go well, just as life will not always be hard. Xiulian was suffering from cancer and the trend 
of happy was break by the "cancer". The author integrates the background of the times and the historical factors in his love and marriage life with the realistic method, and embodies the charm of "serving and taking from the real life".

\section{He is the builder of his home}

The ups and downs of Sun Shaoan's career, achievements and setbacks are all on the Loess Plateau in Northern Shanxi. He has a deep brand of the times. He was a farmer's child bred on the Loess Plateau. He chose to stay in the Shuangshui village and create his own career in his homeland. The traditional virtues of diligence, pragmatism and tenacity of peasants have been fully experienced in him, and the hard life has endowed him with the spirit of continuous struggle and enterprising. Sun Shaoan's life experience made him suffer from the hardships of material poverty life, the pain of stifling political atmosphere and the asininity of the backward modes of production. All these made him more eager to change reality and control his own destiny [3].

After the "gang of four" was crushed, the overall domestic production environment is urgent to be rebuilt. From the experience of his own work, Sun Shaoan felt that many years of collective production made farmers cultivate a serious sense of laziness, which was not conducive to changing the status of extreme poverty. He longed for farmers to have their own land, and thought that farmers were the real masters of the land to help change poverty. When he heard that some of the rural areas of Anhui province has begun to implement the household contract responsibility system, he was determined to make a joint contract. He drew up a contract for production responsibility system after Negotiating with the members, which set off a terrible earthly turmoil on the Loess Plateau. Although before the start of the operation, he foresaw what disaster this action would bring to him. But the revolutionary ideals drive him took the lead to reform even there is huge political risk. As he predicted, the reform of the rural production system that he initiated was not successful. The revolutionary storm was suppressed. Then, when the rural contracted responsibility system was implemented in the whole country, the rural areas in the Loess Plateau began to reform[4].

Sun Shaoan's ability to accept new ideas and new things is relatively well. He made the brick factory prosperous and became the first man "achieve prosperity through working hard" in Shuangshui village and the envy of all. He also hit Shuangshui village. But he was not satisfied with it and immersed himself in his success.He expanded the scale of the brick factory, wanted to get rich with the villagers and help the poor people who lived in poverty. But He lost a lot of money because a worker burned the brickkiln, resulting in the brick factory once unable to continue production. He suffered a painful ordeal. Thanks to his wife's encouragement, he renewed his belief in struggling. He went out of town to make loans and rebuild the brick factory. Under the lesson of failure, he is more down-to-earth. His efforts paid off at last. He made the brick factory to be impressive again. His success attracted the attention of county leaders and made the villagers more eager to become rich. He didn't have the fruits of success alone, but invested to build schools, making contributions to education.

For those who dare to face the challenges and work hard, life will give them back and god of fortune will care for them. They used their hard work to cushion the foundation of their career and build their career with thrift just as Sun Shaoan. His success is inevitable. "An educated gentleman must be resolute and ambitious, for he a great responsibility to society and a long way to go" is a true portrayal of Sun Shaoan's life. He is a real ordinary peasant rising on the bottom of life. His struggle, strive, awakening and life are the true portraiture of that generation. He is full of indomitable fighting spirit."What is life?” Life is endless struggle!" This is the life idea that Mr. Lu Yao wants to express through Sun Shaoan's life track, and this is also the high praise for his entrepreneurship of stoical and indomitable.

\section{Conclusion}

In totally, Sun Shaoan chose an ordinary way to stay at home. He chose to live and start his own business in the poor and ordinary Shuangshui village. For love, he chose an ordinary girl to marry 
and support each other. The characteristics of responsible, rational, dependable, family supremacy, aggressive, innovative, unyielding, enthusiastic and emotional and the perseverance he showed in his business make readers see his extraordinary spiritual world.

\section{Reference}

[1] Ren Guijuan.Analysis of the image connotation of Sun Shaoping and Sun Shaoan in "The ordinary world"[J].Journal of heilongjiang college of education,2008,08:131-132.

[2] Zheng Qian.A brief analysis of Lu Yao's "The ordinary world"[J].Science and technology information,2011,19:643-645.

[3] Tang Siyuan.An analysis of the characters in "The ordinary world"[J].Northern Literature (the second half of the month),2011,11:36-37.

[4] Liu Xiaomei.A study of the characters in "The ordinary world"[J].The Youth Writers,2013,31:73-74. 